DOI: https://doi.org/10.15688/ek.jvolsu.2020.4.5

UDC 332.05

Submitted: 26.10 .2020

LBC 65.049

Accepted: 09.11.2020

\title{
PROBLEMS AND POTENTIAL OF INDUSTRIAL MODERNIZATION IN TAMBOV REGION
}

\author{
Vladislav Yu. Sutyagin \\ Tambov State University named after G.R. Derzhavin, Tambov, Russian Federation \\ Yana Yu. Radyukova \\ Tambov State University named after G.R. Derzhavin, Tambov, Russian Federation
}

\begin{abstract}
The sanctions standoff, the growing global crisis, and the pandemic have exacerbated issues of supporting regional economy. The chronic subsidized nature of Tambov region's economy requires the development of a system of measures to modernize the region's industrial potential. The present study is based on data from Rosstat, Tambovstat, Economic Policy Department of Tambov region. The study analyzes the dynamics and structure of industrial production; assesses the strategic position of the industrial potential of Tambov region; identifies the main constraints to the development of the region's economy. In addition, recommendations are given to accelerate the development of industry in Tambov region. The results of the study can be used for further theoretical research on the development of the industrial potential of the region. The practical aspect of the study is that it is possible to adjust industrial modernization programs in Tambov region based on the results of this study. The results of the study revealed that the acceleration of modernizing the industrial potential of Tambov region requires a solution to several problems, such as eliminating administrative barriers; increasing resource efficiency by reducing energy, resource intensity of production and productivity growth; strengthening the role of the innovation factor in the development of industrial production; expansion of the potential growth industries of the manufacturing sector; deepening the processes of modernization and diversification of industry.

Key words: industrial growth, labor productivity, regional economy, administrative barriers, Tambov region.

Citation. Sutyagin V.Yu., Radyukova Ya.Yu. Problems and Potential of Industrial Modernization in Tambov Region. Vestnik Volgogradskogo gosudarstvennogo universiteta. Ekonomika [Journal of Volgograd State University. Economics], 2020, vol. 22, no. 4, pp. 50-61. (in Russian). DOI: https://doi.org/10.15688/ek.jvolsu.2020.4.5
\end{abstract}

\section{ПРОБЛЕМАТИКА И ПОТЕНЦИАЛ МОДЕРНИЗАЦИИ ПРОМЫШЛЕННОСТИ ТАМБОВСКОЙ ОБЛАСТИ}

\author{
Владислав Юрьевич Сутягин
}

Тамбовский государственный университет им. Г.Р. Державина, г. Тамбов, Российская Федерация

Яна Юрьевна Радюкова

Тамбовский государственный университет им. Г.Р. Державина, г. Тамбов, Российская Федерация 
Аннотация. Санкционное противостояние, нарастание мирового кризиса и пандемия обострили вопросы развития и поддержки региональной экономики. Хронический дотационный характер экономики Тамбовской области требует разработки системы мер по модернизации промышленного потенциала региона. Настоящее исследование базируется на данных Росстата, Тамбовстата, Управления экономической политики Тамбовской области. В рамках данной работы был проведен анализ текущей ситуации в области развития промышленности Тамбовской области, определены тренды развития и выявлены проблемы и препятствия развития промышленного потенциала Тамбовской области, а также оценена проблематика повышения производительности труда в регионе. Кроме того, даны рекомендации по ускорению развития промышленности Тамбовской области. Результаты исследования могут быть использованы в целях дальнейших теоретических разработок по вопросам развития промышленного потенциала региона. Практический аспект проведенного исследования заключается в возможности корректировки на базе результатов настоящего исследования программ модернизации промышленности Тамбовской области. По результатам проведенного исследования было выявлено, что ускорение модернизации промышленного потенциала Тамбовской области требует решения нескольких задач, таких как снятие административных барьеров, повышение эффективности использования ресурсов за счет снижения энерго-, ресурсоемкости производства и роста производительности труда, усиление роли инновационного фактора в развитии промышленного производства, расширение потенциала роста отраслей обрабатывающего сектора промышленности, углубление процессов модернизации и диверсификации промышленности.

Ключевые слова: промышленный рост, производительность труда, региональная экономика, административные барьеры, Тамбовская область.

Цитирование. Сутягин В. Ю., Радюкова Я. Ю. Проблематика и потенциал модернизации промышленности Тамбовской области // Вестник Волгоградского государственного университета. Экономика. - 2020. T. 22, № 4. - C. 50-61. - DOI: https://doi.org/10.15688/ek.jvolsu.2020.4.5

\section{Введение}

Санкционное противостояние со странами ЕС и США, нарастание мирового кризиса резко повысили требования к качеству регионального управления [The Problems ... , 2018]. Дополнительный удар нанесла пандемия COVID-19, сроки окончания которой до сих пор неясны.

Вопросы поддержки региональной экономики и главным образом промышленности региона выходят на первый план. Напомним, что лишь 13 регионов по данным 2019 г. не получали дотаций на выравнивание бюджетной обеспеченности. Это означает, что лишь 13 из 85 субъектов являются финансово самодостаточными [Распределение дотаций ...]. Тамбовская область, к сожалению, не входит в данный перечень.

Пандемия COVID-19 нанесла ощутимый удар и по федеральному бюджету, что в среднесрочной перспективе может снизить объемы финансовой поддержки дотационных регионов.

Однако в стратегическом плане вектор развития экономики региона имеет первостепенное значение. В этой связи в рамках настоящей статьи проанализированы основные проблемы развития Тамбовской области, исследованы слабые и сильные стороны регио- на, а также определены перспективы развития промышленности области.

\section{Методика исследования}

В общетеоретической основе данная работа базировалось на методах анализа, синтеза и индукции. В процессе исследования применялся анализ нормативно-правовых актов федерального и регионального уровней, посвященных реализации национальных проектов и поддержки развития промышленности.

Кроме общенаучных методов в исследовании широко использовались статистические методы, такие как выборочное наблюдение, анализ динамики, структурный анализ, корреляционный анализ. Оценка стратегической позиции промышленности области дана на основе SWOT-анализа.

В рамках выборочного наблюдения анализу подвергались показатели роста промышленности Тамбовской области, в том числе отдельных отраслей и факторов, влияющих на этот рост (например, производительности труда).

Анализ динамики включал исследование показателей роста промышленного производства (отдельных отраслей и факторов) за период с 2015 г. (в отдельных случаях с 2010 г.) 
по 2019 г. (в отдельных случаях по 2018 г.). Выбор временного интервала в значительной степени определялся актуальностью и доступностью статистических данных (особенно в отношении данных за 2019 год).

Структурный анализ предполагал исследование структуры экономики Тамбовской области (в частности, ВРП по отраслям, количество занятых в отраслях экономики, объемы отгруженной продукции по отраслям и т. д.).

Оценка стратегической позиции промышленности области дана в форме SWOT-анализа, в ходе которого были идентифицированы слабые и сильные стороны промышленного потенциала области, а также возникающие возможности и угрозы.

В рамках корреляционного анализа проведена оценка факторов, влияющих на рост производительности труда в Тамбовской области, и даны рекомендации по ее повышению.

Информационной основой проведенного исследования послужили статистические данные Росстата, Тамбовстата, а также Управления экономической политики Тамбовской области. Кроме того, в рамках настоящей статьи мы использовали результаты наших более ранних исследований.

\section{Результаты и обсуждение}

В ходе данного исследования проведена оценка текущего состояния развития промышленности Тамбовской области. Здесь уместно показать динамику развития промышленного производства Тамбовской области в сопоставлении с другими регионами, главным образом регионами ЦФО (табл. 1). Последнее связано с тем фактом, что экономика области экономическими и демографическими связями инкорпорирована со многими регионами ЦФО (в первую очередь с Воронежской, Липецкой, Рязанской, Московской областями и г. Москвой).

Из таблицы 1 можно сделать вывод, что по темпам роста промышленного производства среди 18 регионов ЦФО (по данным за 2015-2019 гг.) Тамбовская область занимает 4-е место. При этом показатель роста заметно выше как общероссийских значений, так и показателей ЦФО.

Индекс промышленного производства в Центральном федеральном округе за период 2015-2019 гг.

\begin{tabular}{|l|r|r|r|r|r|r|}
\hline \multirow{2}{*}{ Субъект РФ } & \multicolumn{5}{|c|}{ Промышленное производство } \\
\cline { 2 - 8 } & 2015 г. & 2016 г. & 2017 г. & 2018 г. & 2019 г. & $\begin{array}{c}\text { Общий } \\
\text { рост }\end{array}$ \\
\hline Российская Федерация & 99,2 & 102,2 & 102,1 & 102,9 & 102,4 & 109,1 \\
\hline $\begin{array}{l}\text { Центральный } \\
\text { федеральный округ }\end{array}$ & 100,3 & 105 & 102,1 & 109,4 & 107,5 & 126,5 \\
\hline Брянская область & 113,9 & 105,9 & 107,3 & 105,2 & 115,6 & 157,4 \\
\hline Московская область & 100,5 & 110,7 & 111,3 & 110,5 & 112,7 & 154,2 \\
\hline Костромская область & 93,6 & 101,7 & 108,6 & 97,6 & 108,7 & 109,7 \\
\hline Тульская область & 110,5 & 114,3 & 106,2 & 105 & 106,7 & 150,3 \\
\hline г. Москва & 98,8 & 100,2 & 101 & 111,1 & 105,3 & 117,0 \\
\hline Воронежская область & 103,5 & 108,1 & 106,7 & 104 & 105,2 & 130,6 \\
\hline Рязанская область & 97,9 & 102,9 & 102 & 104,5 & 104,6 & 112,3 \\
\hline Орловская область & 98,6 & 98,9 & 96,7 & 100,1 & 104,1 & 98,3 \\
\hline Белгородская область & 105 & 105 & 106,1 & 105 & 103,3 & 126,9 \\
\hline Ивановская область & 96,3 & 107,7 & 101,2 & 101,7 & 103,3 & 110,3 \\
\hline Калужская область & 96,9 & 108,4 & 115,1 & 107,3 & 102,8 & 133,4 \\
\hline Смоленская область & 101,9 & 101,1 & 102,8 & 101,4 & 101,8 & 109,3 \\
\hline Тамбовская область & $\mathbf{1 0 5 , 2}$ & $\mathbf{1 0 4 , 1}$ & $\mathbf{1 1 0 , 1}$ & $\mathbf{1 1 4 , 8}$ & $\mathbf{1 0 1 , 5}$ & $\mathbf{1 4 0 , 5}$ \\
\hline Тверская область & 97,7 & 105,5 & 101,8 & 113,1 & 101,3 & 120,2 \\
\hline Липецкая область & 100,5 & 103,4 & 103 & 105,1 & 100 & 112,5 \\
\hline Курская область & 104,5 & 104,7 & 103,1 & 103,6 & 99,7 & 116,5 \\
\hline Ярославская область & 102,2 & 106,8 & 114,2 & 109,9 & 98,4 & 134,8 \\
\hline Владимирская область & 99,4 & 96,8 & 100,6 & 101,9 & 98 & 96,7 \\
\hline
\end{tabular}

Примечание. Источник: [Индексы ...]. 
В.Ю. Сутягин, Я.Ю. Радюкова. Проблематика и потенциал модернизации промышленности

Однако в абсолютных цифрах регион находится далеко не на лидирующих позициях. Так, по состоянию на 2018 г. валовой региональный продукт (далее - ВРП) Тамбовской области составил 331,6 млрд руб. (54-й результат из 85 субъектов РФ). Для сравнения: г. Москва - 17 881,5 млрд руб.; Ханты-Мансийский автономный округ - 4 447,5 млрд руб.; Московская область - 4 201,8 млрд руб.; Белгородская область - 866,0 млрд руб.; Воронежская область - 943,6 млрд руб.; Липецкая область 580,5 млрд руб. [Регионы России ... , 2019].

Одним из ключевых преимуществ экономики региона выступает ее диверсифицированный характер (табл. 2).

Явными локомотивами экономического роста последних лет являются сельское хозяйство, торговля и строительство. Первое является особенно важным в условиях высокой динамики развития российского сельского хозяйства последних десяти лет. Напротив, настораживают относительно низкие показатели вклада промышленности области.

Оценку стратегической позиции промышленности области наглядно можно представить в виде матрицы SWOT-анализа (см. табл. 3).
Следует заметить, что в настоящий момент при наличии всех очевидных сильных сторон промышленности области (главным образом связанных с географическим положением и сектором АПК) преобладающими являются слабые стороны. Обращает на себя внимание разноплановый характер идентифицированных слабостей, что в управленческом плане создает значительные проблемы. Основные возможности развития промышленности области, как видится, находятся в управленческом аспекте, если быть точнее, в соответствии региональных организационных инициатив федеральным планам (в частности, национальным проектам). В первую очередь ключевые угрозы связаны с демографической ситуацией области и наличием административных барьеров. По нашим оценкам, в рамках базового прогноза население области сократится на $3,8 \%$ к 2024 г., (оптимистический прогноз на $3,4 \%$, а реалистический прогноз - на $4,3 \%$ ) (см. рисунок).

Задачи повышения эффективности производства и ускорения роста производительности труда в настоящее время являются

Структура ВРП Тамбовской области (по данным 2018 г.), \%

Таблииа 2

\begin{tabular}{|c|c|}
\hline Отрасль & 2018 г. \\
\hline Сельское, лесное хозяйство, охота, рыболовство и рыбоводство & 24,7 \\
\hline Добыча полезных ископаемых & 0,0 \\
\hline Обрабатывающие производства & 13,1 \\
\hline Обеспечение электрической энергией, газом и паром; кондиционирование воздуха & 2,2 \\
\hline $\begin{array}{l}\text { Водоснабжение; водоотведение, организация сбора и утилизация отходов, деятельность по } \\
\text { ликвидации загрязнений }\end{array}$ & 0,4 \\
\hline Строительство & 12,3 \\
\hline Торговля оптовая и розничная; ремонт автотранспортных средств и мотоциклов & 16,0 \\
\hline Транспортировка и хранение & 6,6 \\
\hline Деятельность гостиниц и предприятий общественного питания & 0,8 \\
\hline Деятельность в области информации и связи & 1,9 \\
\hline Деятельность финансовая и страховая & 0,3 \\
\hline Деятельность по операциям с недвижимым имуществом & 3,6 \\
\hline Деятельность профессиональная, научная и техническая & 1,4 \\
\hline Деятельность административная и сопутствующие дополнительные услуги & 1,4 \\
\hline $\begin{array}{l}\text { Государственное управление и обеспечение военной безопасности; социальное } \\
\text { обеспечение }\end{array}$ & 6,1 \\
\hline Образование & 3,7 \\
\hline Деятельность в области здравоохранения и социальных услуг & 4,4 \\
\hline Деятельность в области культуры, спорта, организации досуга и развлечений & 0,6 \\
\hline Предоставление прочих видов услуг & 0,5 \\
\hline
\end{tabular}

Примечание. Составлено по: [Структура ...]. 
ключевыми как для российской экономики в целом, так и для экономики Тамбовской области в частности. О важности этого говорит тот факт, что на федеральном уровне в рамках Указа Президента Российской Федерации от 7 мая 2018 г. № 204 «О национальных целях и стратегических задачах развития Российской Федерации на период до 2024 года» [Указ Президента РФ от 07.05.2018 № 204 ...] принят национальный проект «Производительность труда и поддержка занятости». Обращаем внимание, что Тамбовская область подошла довольно ответственно к реализации этого национального проекта.

В рамках реализации мероприятий национального проекта «Производительность труда и поддержка занятости» Тамбовская область выбрана в качестве пилотного региона для проведения «Фабрики офисных процес- сов», разработанной по стандартам АНО «Федеральный центр компетенций в сфере производительности труда».

Далее проанализируем производительность труда в Тамбовской области (см. табл. 4).

В рамках настоящего исследования показатель производительности труда рассчитан как отношение объема отгруженных товаров на среднесписочную численность работников.

Обращает на себя внимание заметный рост производительности труда. Более того, только за последние пять лет этот показатель вырос почти на $67 \%$.

Проанализируем, в какой степени на производительность труда влияют такие факторы, как:

- среднемесячная номинальная начисленная заработная плата;

\section{Результаты SWOT-анализа промышленности Тамбовской области}

Таблииа 3

\begin{tabular}{|c|c|}
\hline S = Strengths - сильные стороньы & W=Weaknesses - слабые стороны \\
\hline $\begin{array}{l}\text { 1. Выгодное геостратегическое положение. } \\
\text { 2. Наличие серьезной образовательной и научно- } \\
\text { исследовательской базы. } \\
\text { 3. Наличие плодородной почвы. } \\
\text { 4. Мощная пищевая промышленность }\end{array}$ & $\begin{array}{l}\text { 1. Низкий уровень развития инфраструктуры. } \\
\text { 2. Наличие незначительного перечня товаров и ус- } \\
\text { луг, способных конкурировать на российском и ми- } \\
\text { ровом рынках. } \\
\text { 3. Рассеивание научно-технического потенциала } \\
\text { региона. } \\
\text { 4. Развитие преимущественно крупного и среднего } \\
\text { предпринимательства. } \\
\text { 5. Недостаток финансовых ресурсов и инвестиций. } \\
\text { 6. Сокращение населения (естественная убыль, } \\
\text { миграционный отток). } \\
\text { 7. Низкая ориентированность промышленности } \\
\text { субъекта на покупательский спрос. } \\
\text { 8. Отсутствие крупных месторождений полезных } \\
\text { ископаемых }\end{array}$ \\
\hline O=Opportunities - возможнности & $T=$ Threats - угрозы \\
\hline $\begin{array}{l}\text { 1. Федеральная поддержка развития малого и среднего } \\
\text { предпринимательства (в том числе в рамках националь- } \\
\text { ного проекта «Малое и среднее предпринимательство и } \\
\text { поддержка индивидуальной предпринимательской ини- } \\
\text { циативы». } \\
\text { 2. Повышение производительности труда (в том числе в } \\
\text { рамках национального проекта «Производительность } \\
\text { труда и поддержка занятости»). } \\
\text { 3. Эффективное использование возобновляемых при- } \\
\text { родных ресурсов и повышение энергоэффективности. } \\
\text { 4. Автоматизация и цифровизация экономических про- } \\
\text { цессов («Цифровая экономика). } \\
\text { 5. Включение Тамбовской области в крупный инфраструк- } \\
\text { турный проект «ападная Европа - Западный Китай». } \\
\text { 6. Сравнительно низкий уровень заработной платы, по- } \\
\text { вышающий привлекательность в глазах инвесторов }\end{array}$ & $\begin{array}{l}\text { 1. Нестабильность рынков: финансового, кредит- } \\
\text { ного и сбыта продукции. } \\
\text { 2. Несовершенство нормативно-правовой базы. } \\
\text { 3. Ограничение возможности воспроизводства } \\
\text { ключевого ресурса - человеческого капитала в со- } \\
\text { циально-экономическом развитии на среднесроч- } \\
\text { ную и долгосрочную перспективы. } \\
\text { 4. Вытеснение с рынка местных производителей } \\
\text { конкурентами из других городов. } \\
\text { 5. На фоне экономического кризиса сокращение } \\
\text { числа юридических лиц и индивидуальных пред- } \\
\text { принимателей. } \\
\text { 6. Наличие административных барьеров, сдержи- } \\
\text { вающих экономическое развитие региона }\end{array}$ \\
\hline
\end{tabular}

Примечание. Составлено авторами. 
В.Ю. Сутягин, Я.Ю. Радюкова. Проблематика и потенциал модернизации промышленности

- доля внутренних затрат на исследования и разработки в валовом региональном продукте.

Это позволит понять, на какие факторы следует воздействовать в дальнейшем. Результаты корреляционного анализа представлены в таблице 5.
Таким образом, весьма высокое влияние на производительность труда оказывает среднемесячная номинальная начисленная заработная плата (коэффициент парной корреляции $r=0,973)$. Коэффициент детерминации $\left(r^{2}\right)$ составляет 0,949. Это означает, что практически в $95 \%$ случаев изменение производитель-

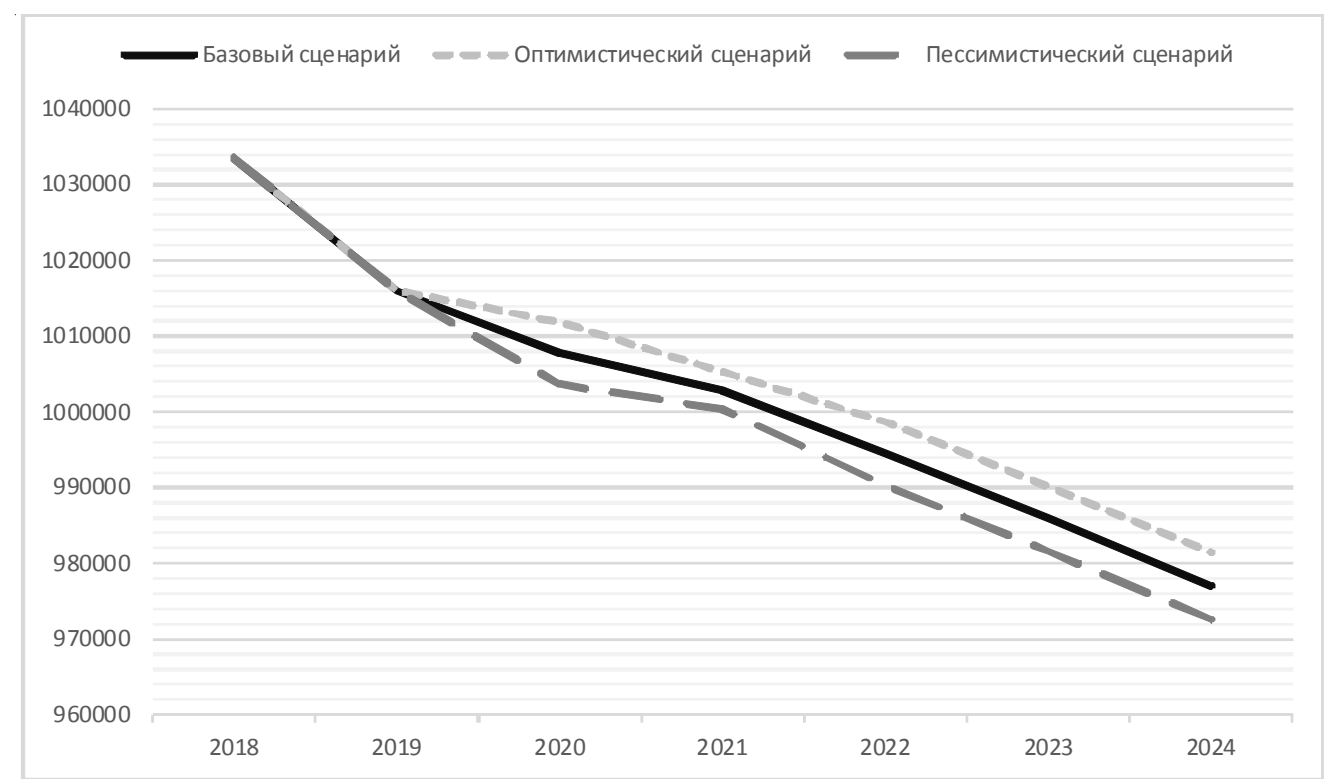

Рисунок. Прогнозная динамика сокращения населения Тамбовской области на период до 2024 г. (по разным прогнозным вариантам)

Примечание. Источник: [Сутягин, 2020].

Таблица 4

Основные показатели, влияющие на производительность труда Тамбовской области в отрасли обрабатывающих производств в 2010-2018 гг.

\begin{tabular}{|c|c|c|c|c|c|c|c|c|c|}
\hline Показатель & 2010 г. & $2011 г$. & 2012 г. & $2013 г$. & 2014 г. & 2015 г. & 2016 г. & 2017 г. & 2018 г. \\
\hline $\begin{array}{l}\text { Объем отгруженных товаров } \\
\text { собственного производства, } \\
\text { выполненных работ и услуг } \\
\text { собственными } \\
\text { млн руб. в факти ческих дейст- } \\
\text { вовавших ценах } \\
\end{array}$ & 50412,8 & 80490 & 83331 & 89453 & 100852 & 122324,8 & 137364,2 & 134328,6 & 162991,2 \\
\hline $\begin{array}{l}\text { Среднесп исочная численность } \\
\text { работников, тыс. чел. }\end{array}$ & 51,2 & 50,5 & 51 & 51,9 & 51,2 & 49,9 & 49,5 & 45,5 & 49,6 \\
\hline $\begin{array}{l}\text { Среднемесячная номинальная } \\
\text { начисленная заработная плата } \\
\text { работников, руб. }\end{array}$ & 12769,4 & 14318,3 & 16524,7 & 18638,3 & 21195,1 & 22863,3 & 24223,5 & 26797 & 27807,3 \\
\hline $\begin{array}{l}\text { Доля внутренних затрат на } \\
\text { исследования и разработки в } \\
\text { ВРП, \% }\end{array}$ & 0,56 & 0,53 & 0,47 & 0,61 & 0,8 & 0,69 & 0,56 & 0,36 & н/д \\
\hline $\begin{array}{l}\text { Доля продукции } \quad \text { высокотех- } \\
\text { нологичных и и наукоемких } \\
\text { отраслей в ВРП, \% }\end{array}$ & 17,3 & 17,6 & 17,2 & 17,5 & 15,5 & 17,7 & 17,2 & $\mathrm{H} /$ д & н/д \\
\hline $\begin{array}{l}\text { Производительность } \\
\text { тыс. руб./чел. }\end{array}$ & 984,6 & 1593,9 & 1633,9 & 1723,6 & 1969,8 & 2451,4 & 2775,0 & 2952,3 & 3286,1 \\
\hline
\end{tabular}

Примечание. Источник: [Статистический ежегодник, 2019]. 
ности труда обусловлено изменением размера начисленной заработной платы. Примечательно, что между показателем производительности труда и уровнем заработной платы существует прямая взаимосвязь (хотя математически, судя по формуле, должна быть обратная). Дело в том, что с 2010 по 2018 г. объемы реализации (производства) продукции выросли в 3,23 раза, тогда как заработная плата - в 2,17 раз. В такой ситуации низкий уровень заработной платы в области стал главным резервом роста производительности на предприятиях региона. Вместе с тем низкий уровень заработных плат влияет на платежеспособный спрос в регионе, что в будущем скажется на объемах производства и отгрузки продукции. Следовательно, дальнейший рост производительности труда за счет сдерживания роста заработных плат существенно ограничен. Напротив, между производительностью труда и затратами на исследования и разработки - отрицательная взаимосвязь (коэффициент парной корреляции $r=-0,174)$. Это означает, что данный фактор фактически был не задействован, что очевидно, если учитывать ситуацию с заработными платами. Здесь нужно сказать, что именно НИОКР могут стать прорывом в дальнейшем наращивании производительности труда.

В этой связи как нельзя кстати стала разработка региональными властями нескольких соглашений о реализации проектов в сфере повышения уровня производительности труда:
- «Адресная поддержка повышения производительности труда на предприятиях»;

- «Системные меры по повышению производительности труда»;

- «Поддержка занятости и повышение эффективности рынка труда для обеспечения роста производительности труда (Тамбовская область)».

В рамках национального проекта «Производительность труда и поддержка занятости» к концу 2019 г. 8 промышленных предприятий индустриальных отраслей (АО «Арти-завод», АО «Арти-Резинопласт», АО «Милорем», АО «ТЗ Октябрь», ПАО «Пигмент», АО «Росхимзащита», $\mathrm{AO}$ «ТАГАТ», $\mathrm{AO}$ «Тамбовмаш») стали участниками регионального проекта, а в 2019 г. с ними были заключены соглашения.

В ходе реализации регионального проекта «Поддержка занятости и повышение эффективности рынка труда для обеспечения роста производительности труда» работники предприятий в течение года прошли опережающее профессиональное обучение. Так, на ПАО «Пигмент», АО «Тамбовмаш» Федеральным центром компетенций был проведен анализ текущего состояния предприятий, определены основные мероприятия, направленные на увеличение производительности труда, в том числе на возможность применения инструментов бережливого производства.

Несмотря на столь короткий период реализации проектов повышения производительности труда, уже выявлен ряд проблем, препятствующих их развитию:

Таблица 5

\section{Матрица корреляции показателей производительности труда, среднемесячной номинальной заработной платы, доли внутренних затрат на исследования и разработки в ВРП Тамбовской области}

\begin{tabular}{|l|c|c|c|}
\hline & $\begin{array}{l}\text { Производитель- } \\
\text { ность труда, } \\
\text { тыс. руб./чел. }\end{array}$ & $\begin{array}{l}\text { Среднемесячная номиналь- } \\
\text { ная начисленная заработная } \\
\text { плата работников, руб. }\end{array}$ & $\begin{array}{l}\text { Доля внутренних за- } \\
\text { трат на исследования и } \\
\text { разработки в ВРП, \% }\end{array}$ \\
\hline $\begin{array}{l}\text { Производительность тру- } \\
\text { да, тыс. руб./чел. }\end{array}$ & 1 & & \\
\hline $\begin{array}{l}\text { Среднемесячная номи- } \\
\text { нальная начисленная за- } \\
\text { работная плата работни- } \\
\text { ков, руб. }\end{array}$ & 0,973 & 1 & 1 \\
\hline $\begin{array}{l}\text { Доля внутренних затрат на } \\
\text { исследования и разработки } \\
\text { в ВРП, \% }\end{array}$ & $-0,174$ & $-0,054$ & \\
\hline
\end{tabular}

Примечание. Источник: [Сутягин, 2020]. 
1. Административные барьеры. Как на федеральном, так и на региональном уровне большинство административных процедур усложнены, что приводит к коррупции и снижает результаты деятельности предприятия, а также ослабляет степень конкуренции внутри любой отрасли экономической деятельности.

2. Устаревшие техника и технологии производства. С каждым годом растет уровень износа основных фондов. Это свидетельствует о том, что техника и технологии обновляются несвоевременно.

3. Недостаточный объем инвестиций. В кризисный период не происходит высокого подъема уровня инвестиций в основной капитал, что приводит к снижению производительности труда.

4. Низкая квалификация работников. По мере того как растет уровень образования и квалификации работников, увеличивается производительность труда, что способствует повышению уровня и темпов экономического роста. Иначе говоря, затраты труда могут расширяться без какого-либо увеличения рабочего времени и численности занятых, а лишь за счет повышения качества рабочей силы.

5. Несоответствие трудового законодательства потребностям экономики - одна из главных причин наличия неквалифицированных рабочих кадров.

6. Недостаточное стимулирование работников. Для роста производительности труда необходимо увеличение гибкости персонала, так как повышения уровня заработной платы недостаточно.

Ответом на обозначенную проблематику могло бы стать:

1. Стимулирование роста конкуренции путем устранения административных барьеров. Формирование конкурентной среды и обеспечение равных условий конкуренции должны стать для органов государственной власти приоритетной задачей.

2. Повышение технического уровня производства путем внедрения новых технологических процессов, проведения технологической модернизации, автоматизации производственной и управленческой деятельности.

3. Увеличение объема инвестиций за счет разработки более эффективной системы выхода на рынки других регионов и стран (поддержка экспорта продукции предприятий региона). В этой связи важная роль отводится реализации национального проекта «Международная кооперация и экспорт».

4. Модернизация системы профессионального образования и переподготовки кадров, которая включает в себя организацию и проведение программ по повышению квалификации руководящих кадров высшего и среднего звеньев, развитие системы внутрипроизводственного обучения, повышение квалификации работников, в том числе за счет задействования ресурсов национального проекта «Образование».

5. Разработка эффективной системы мотивации персонала путем проведения сбора и анализа информации о существующих мерах; опросов среди сотрудников о наиболее выгодных для них стимулов.

Исходя из проведенного анализа состояния промышленности Тамбовской области, характеристики производительности труда и анализа сильных и слабых сторон региона, можно сделать некоторые выводы относительно прогнозов развития промышленности до 2024 года.

Здесь следует оговориться. Управлением экономической политики подготовлен двухвариантный (консервативный и базовый) сценарий развития экономики Тамбовской области до 2024 года. Отличия по вариантам объясняются различной степенью воздействия внешнеэкономической конъюнктуры на темпы роста экономики области, различной динамикой развития основных отраслей и сфер региональной экономики, эффективностью предпринимаемых мер по обеспечению устойчивого развития экономики и социальной стабильности в регионе.

Основными задачами и перспективами развития промышленного комплекса на текущий период и среднесрочный период являются:

1. Сохранение положительной динамики промышленного производства.

2. Эффективное взаимодействие с федеральными министерствами с целью привлечения всех предусмотренных мер поддержки в сфере промышленности.

3. Взаимодействие с институтами развития с целью максимального привлечения средств всех уровней. 
4. Оказание содействия в загрузке предприятий оборонно-промышленного комплекса области гражданской продукцией, проведении диверсификации производства.

5. Включение индустриальных парков области в федеральный реестр парков с целью последующего возмещения затрат на создание инфраструктуры из федерального бюджета и обеспечение наполнения парков резидентами для оживления экономики области.

6. Участие промышленных предприятий области в реализации национальных проектов.

По прогнозу, среднегодовой темп роста промышленного производства области за 2019-2024 гг. составит 102,6 \% и 103,8 \% по консервативному и базовому вариантам соответственно [Об утверждении прогноза, 2019].

В обрабатывающих производствах за 2019-2024 гг. прогнозируется среднегодовой рост объемов промышленного производства на уровне $102,8 \%$ и $104,1 \%$ согласно вариантам [Постановление Администрации Тамбовской области от 16.01.2019 № 24 ...].

В таблице 6 представлены целевые показатели по отраслям промышленности к 2024 году.

Следует отметить, что драйвером экономического развития Тамбовской области является АПК. На среднесрочную перспективу производство пищевых продуктов будет занимать одно из ведущих мест в промышленности области за счет реализации масштабных инвестиционных проектов в таких отраслях, как мясная, сахарная, производство растительных масел, глубокая переработка сельскохозяйственной продукции (ОАО «Токаревская птицефабрика», ООО «Тамбовская индейка», ООО «Тамбовский бекон», ООО «ФИЛЬЕ», ООО «Сабуровский комбинат хлебопродуктов», ООО «Кристалл», ООО «Ладесол-Тамбов» по производству концентрированных белковых продуктов).

Реализация крупномасштабных проектов в АПК позволит увеличить производство мяса и субпродуктов пищевых убойных животных в 2024 г. в 2,0 раза к уровню 2018 г. (в базовом варианте); производство мяса птицы - на $10 \%$; производство комбикормов - в 1,2 раза; производство сахара белого свекловичного в твердом состоянии - в 1,2 раза; масел растительных нерафинированных - в 2,1 раза.

Среднегодовой темп роста за 2019-2024 гг. по первому и второму вариантам составит $103,6 \%$ и $107,1 \%$ соответственно, что заметно ниже средних темпов роста по промышленности [Постановление Администрации Тамбовской области от 16.01.2019 № 24 ...].

\section{Выводы}

Промышленность Тамбовской области в последнее десятилетие показывает устойчивую и довольно высокую динамику развития. Вместе с тем экономический потенциал области довольно низок. В значительной степени это связано с наследием 1990-х и начала 2000-х гг., когда агропромышленный потенциал был практически

\section{Целевые показатели развития промышленности Тамбовской области по отраслям к 2024 г.}

\begin{tabular}{|l|c|c|c|}
\hline \multicolumn{1}{|c|}{ Показатель } & $\begin{array}{c}\text { Занятые, } \\
\text { тыс. чел. }\end{array}$ & $\begin{array}{c}\text { Отгрузка, } \\
\text { млрд руб. }\end{array}$ & $\begin{array}{c}\text { На 1 рабочего, } \\
\text { млн руб. }\end{array}$ \\
\hline Всего & 62,3 & 279 & 4,5 \\
\hline $\begin{array}{l}\text { В том числе: } \\
\text { пищевая промышленность }\end{array}$ & 14,4 & - & - \\
\hline легкая промышленность & 4,3 & 7,9 & 1,8 \\
\hline обработка древесины и изделия из дерева & 1,8 & 4,9 & 2,7 \\
\hline химическая промышленность & 3,5 & 15,8 & 4,5 \\
\hline производство строительных материалов & 4,3 & 15,7 & 3,7 \\
\hline $\begin{array}{l}\text { металлургическая промышленность и } \\
\text { производство металлических изделий }\end{array}$ & 1,7 & 13,4 & 7,9 \\
\hline машиностроение & 14,5 & 32,8 & 2,3 \\
\hline производство транспортных средств & 5,2 & 21,8 & 4,2 \\
\hline
\end{tabular}

Примечание. Составлено по: [Постановление Администрации Тамбовской области от 16.01.2019 № 24 ...]. 
уничтожен. В статистическом плане высокие темпы роста по сравнению с другими регионами могут трактоваться как эффект низкой базы. Впрочем, нельзя недооценивать системную работу региональных органов власти за последние 5-7 лет. Инициативный характер такой работы заметен не только в статистических показателях, но и в постоянном участии в пилотных федеральных проектах и активном включении региона в реализацию национальных проектов.

Вместе с тем показатели роста, скорее всего, будут замедляться. Главным долгосрочным негативом выступает тот факт, что регион является хронически дотационным, а это сдерживает финансовые возможности по стимулированию промышленности области. Второй негативный момент - это санкционное давление на Россию и нарастание мирового кризиса, что будет сдерживать возможности федерального бюджета по поддержке регионов. Наконец, третий и в среднесрочном плане важнейший фактор - развитиепандемии COVID-19, что наносит сильный удар по потребительскому спросу и промышленному росту.

Ускорение долгосрочного тренда промышленного роста области требует решения нескольких задач:

- снятие административных барьеров (отмечены выше), особенно тех, которые могут быть разрешены на региональном уровне;

- повышение эффективности использования ресурсов за счет снижения энерго-, ресурсоемкости производства и роста производительности труда;

- усиление роли инновационного фактора в развитии промышленного производства, в том числе за счет цифровизации производств;

- расширение потенциала роста отраслей обрабатывающего сектора промышленности;

- углубление процессов модернизации и диверсификации промышленности.

\section{СПИСОК ЛИТЕРАТУРЫ}

Индексы промышленного производства по субъектам Российской Федерации // Росстат. - Электрон. текстовые дан. - Режим доступа: https:// rosstat.gov.ru/storage/mediabank/ind prom_sub.xls (дата обращения: 04.10.2020). - Загл. с экрана.

Постановление Администрации Тамбовской области от 16.01.2019 № 24 «Об утверждении прогноза социально-экономического развития Тамбовской области на долгосрочный период до 2035 года» // Консорциум Кодекс. - Электрон. текстовые дан. - Режим доступа: http://docs.cntd.ru/document/ 550320438 (дата обращения: 12.04.2020). Загл. с экрана.

Распределение дотаций на выравнивание бюджетной обеспеченности субъектов Российской Федерации на 2019 год, тыс. рублей // Минфин РФ. - Электрон. текстовые дан. - Режим доступа: https://www.minfin.ru/common/upload/ library/2018/12/main/FFPR_2019_-2021.pdf (дата обращения: 04.10.2020). - Загл. с экрана.

Регионы России. Социально-экономические показатели - 2019 // Росстат. - Электрон. текстовые дан. - Режим доступа: https://rosstat.gov.ru/ bgd/regl/b19_14p/Main.htm (дата обращения: 04.10.2020). - Загл. с экрана.

Статистический ежегодник, 2019 : стат. сб. - Тамбов : Тамбовстат, 2019. - $151 \mathrm{c.}$

Структура валовой добавленной стоимости по видам экономической деятельности по ОКВЭД 2 по Тамбовской области за 2016-2018 гг. // Тамбовстат. - Электрон. текстовые дан. - Режим доступа: https://mb.gks.ru/storage/mediabank/ struktura_\%D0\%9E\%D0\%9A\%D0\%92\% D0\%AD\%D0\%942.pdf (дата обращения: 04.10.2020). - Загл. с экрана.

Сутягин, В. Ю. Прогноз трудовых ресурсов региона как фактор экономического развития / В. Ю. Сутягин // Ученые записки Тамбовского отделения PoСМУ.-2020. -№ 19.-C. 45-57.

Сутягин, В. Ю. Трудовые ресурсы региона как фактор обеспечения долгосрочного экономического роста / В. Ю. Сутягин, Я. Ю. Радюкова // Вестник Северо-Кавказского федерального университета. - 2020. - № 3 (78). C. $80-95$.

Указ Президента Российской Федерации от 07.05.2018 № 204 «О национальных целях и стратегических задачах развития Российской Федерации на период до 2024 года» // Президент России. Электрон. текстовые дан. - Режим доступа: http://www.kremlin.ru/acts/bank/43027 (дата обращения: 04.10.2020). - Загл. с экрана.

The Problems of Financial Security of Modern Russia / V. Sutyagin [et al.] // Proceedings of the $32^{\text {nd }}$ International Business Information Management Association Conference (IBIMA) / ed. by Kh. S. Soliman. [S. 1. : s. n.], 2018. - C. 2877-2888. 


\section{REFERENCES}

Indeksy promyshlennogo proizvodstva po subyektam Rossijskoj Federacii [Indices of Industrial Production by Regions of the Russian Federation]. Rosstat. URL: https://rosstat.gov.ru/ storage/mediabank/ind_prom_sub.xls (accessed 4 October 2020).

Postanovlenie Administracii Tambovskoj oblasti ot 16.01.2019 № 24 «Ob utverzhdenii prognoza social'no-jekonomicheskogo razvitija Tambovskoj oblasti na dolgosrochnyj period do 2035 goda» [On Approval of the Forecast of Socio-Economic Development of Tambov Region for the Long-Term Period up to 2035]. Konsorcium Kodeks [Consortium Codex]. URL: http://docs.cntd.ru/document/550320438 (accessed 12 April 2020).

Raspredelenie dotacij na vyravnivanie bjudzhetnoj obespechennosti subyektov Rossijskoj Federacii na 2019 god, tys. rublej [Distribution of Subsidies for Equalizing the Budget Security of the Subjects of the Russian Federation for 2019, Thousand Rubles]. Minfin RF [Ministry of Finance of the Russian Federation]. URL: https:/www.minfin.ru/common/upload/library/ 2018/12/main/FFPR_2019_-2021.pdf(accessed 4 October 2020).

Regiony Rossii. Social'no-jekonomicheskie pokazateli 2019 [The Regions of Russia. Socio-Economic Indicators 2019]. Rosstat. URL: https:// rosstat.gov.ru/bgd/regl/b19_14p/Main.htm (accessed 4 October 2020).

Statisticheskij ezhegodnik, 2019: stat. sb. [Statistical Yearbook, 2019. Statistical Compilation]. Tambov, Tambovstat, 2019. $151 \mathrm{p}$.

Struktura valovoj dobavlennoj stoimosti po vidam jekonomicheskoj dejatel'nosti po OKVJeD 2 po
Tambovskoj oblasti za 2016-2018 gg. [Structure of Gross Value Added by Types of Economic Activity for OKVED 2 in Tambov Region for 2016-2018] Tambovstat. URL: https://tmb.gks.ru/ storage/mediabank/struktura_\%D0\%9E $\%$ D0\%9A\%D0\%92\%D0\%AD\%D0\%942.pdf (accessed 4 October 2020).

Sutjagin V.Ju. Prognoz trudovyh resursov regiona kak faktor jekonomicheskogo razvitija [Forecast of Labor Resources of the Region as a Factor of Economic Development]. Uchenye zapiski Tambovskogo otdelenija RoSMU, 2020, no. 19, pp. 45-57.

Sutjagin V.Ju., Radjukova Ja.Ju. Trudovye resursy regiona kak faktor obespechenija dolgosrochnogo jekonomicheskogo rosta [Labor Resources of the Region as a Factor of Ensuring Long-Term Economic Growth]. Vestnik Severo-Kavkazskogo federal'nogo universiteta, 2020, no. 3 (78), pp. 80-95.

Ukaz Prezidenta Rossijskoj Federacii ot 07.05.2018 g. № 204 «O nacional’nyh celjah i strategicheskih zadachah razvitija Rossijskoj Federacii na period do 2024 goda» [Decree of the President of the Russian Federation No. 204 of May 7, 2018 “On National Goals and Strategic Objectives of the Development of the Russian Federation for the Period up to 2024"]. Prezident Rossii [President of the Russian Federation]. URL: http:// www.kremlin.ru/acts/bank/43027 (accessed 4 October 2020).

Sutyagin V., Radyukova Ya., Treschevsky Yu.I., Artemenko D.A. The Problems of Financial Security of Modern Russia. Khalid S. Soliman, ed. Proceedings of the $32^{\text {nd }}$ International Business Information Management Association Conference (IBIMA). [S. 1. : s. n.], 2018, pp. 2877-2888. 
В.Ю. Сутягин, Я.Ю. Радюкова. Проблематика и потенциал модернизации промышленности

\section{Information About the Authors}

Vladislav Yu. Sutyagin, Candidate of Sciences (Economics), Associate Professor, Associate Professor, Department of Finance and Banking, Tambov State University named after G.R. Derzhavin, Internatsionalnaya St, 33, 392000 Tambov, Russian Federation, sutyagin.vladislav@yandex.ru, https://orcid.org/0000-0002-3223-3875

Yana Yu. Radyukova, Candidate of Sciences (Economics), Associate Professor, Head of the Department of Finance and Banking, Tambov State University named after G.R. Derzhavin, Internatsionalnaya St, 33, 392000 Tambov, Russian Federation, radyukova68@mail.ru, https://orcid.org/0000-0002-9270-494X

\section{Информация об авторах}

Владислав Юрьевич Сутягин, кандидат экономических наук, доцент кафедры финансов и банковского дела, Тамбовский государственный университет им. Г.Р. Державина, ул. Интернациональная, 33, 392000 г. Тамбов, Российская Федерация, sutyagin.vladislav@yandex.ru, https://orcid.org/0000-0002-3223-3875

Яна Юрьевна Радюкова, кандидат экономических наук, доцент, заведующая кафедрой финансов и банковского дела, Тамбовский государственный университет им. Г.Р. Державина, ул. Интернациональная, 33, 392000 г. Тамбов, Российская Федерация, radyukova68@mail.ru, https://orcid.org/0000-0002-9270-494X 